Gianvito Brindisi. Research fellow in Public Law at the Università degli Studi di Napoli "Parthenope". He collaborates with the Chair of Philosophy of Law at the Università degli Studi di Napoli "Suor Orsola Benincasa". His main research interests focus on the relationship between theories of power and theories of law and on the philosophical and sociological analysis of judgment and judicial practices, especially in relation to powers, knowledges and forms of subjectivity.

Contact: gvbrindisi@libero.it 


\section{JUDICIAL POWER AND GOVERNMENTALITY IN MICHEL FOUCAULT}

\section{A Method for Considering the Form of Rationality of Judicial Governance}

\section{Gianvito Brindisi}

Università degli Studi di Napoli "Parthenope"

Reception date April $9^{\text {th }}$ 2015; Acceptance date may $7^{\text {th }}$ 2015. This article is developed within PRIN project (2010-2011) titled "Giurisdizione e pluralismi", held at the Dipartimento di Giurisprudenza of the Università degli Studi di Napoli "Parthenope".

\section{Abstract}

This article intends to offer a methodological clarification of Foucault's genealogy in relation to judicial practice, with the aim to apply it to judicial governance. In particular, it shows that beyond the distinctive questions of the debate on government by judges (creation of law and democratic legitimacy), a specific form of judicial governmentality has been created since $19^{\text {th }}$ century, through the complex relationship of judiciary with technologies of power and forms of knowledge. The article tries to demonstrate that the problem of the government by judges can be rewritten and that judicial governance constitutes a new chapter of the judicial governmentality, a form of governmentality that makes the expertising the result of our legal and moral history.

\section{Keywords}

Michel Foucault, judicial governance, judicial governmentality, legal globalization. 


\section{Resumen}

Este artículo pretende aclarar metodológicamente la genealogía de Foucault en relación con la práctica judicial, con la finalidad de aplicarla a la gobernanza judicial. En particular, se pretende mostrar que, más allá de las clásicas problemáticas del debate sobre el gobierno de los jueces (creación de derecho y legitimación democrática), desde hace el siglo XIX se creó una forma específica de gubernamentalidad judicial, gracias a una compleja relación de lo judicial con tecnologías de poder y formas de saber. El artículo intenta demostrar que el problema del gobierno de los jueces se puede volver a escribir y que la gobernanza judicial constituye un nuevo capítulo de la gubernamentalidad judicial, una forma de gubernamentalidad que convierte el expertising en el resultado de nuestra historia jurídica y moral.

\section{Palabras clave}

Michel Foucault, gobernanza judicial, gubernamentalidad judicial, globalización jurídica.

\section{The Judicial Power in Foucauldian Method}

Since the debate on the global expansion of judicial power has exploded, towards the end of the 20th century, a wide literature has attempted to grasp its most significant aspects, also by reactivating old categories (government of judges), or inventing new ones (judicial governance). ${ }^{1}$ With this study we would like to add some considerations to the debate by emphasizing the capability of social regulation exercised by judges in a complex field of governmentality. And we would like to do this through Michel Foucault's methodology, because we believe that judicial governmentality is a field in which his thought may express its hermeneutic power. An analysis which starts from Foucault's categories requires, however, a preliminary determination of the methodological core through which Foucault considered transformations of the judicial power. Therefore, the Foucault's method will be synthetically illustrated and then we will show

1. See at least C.N. Tate, T. Vallinder (eds.), The Global Expansion of Judicial Power, New York University Press, New York-London, 1995; S. Brondel, N. Foulquier, L. Heuschling (eds.), Gouvernement des juges et démocratie, Publications de la Sorbonne, Paris, 2001; M. Shapiro, A. Stone Sweet (eds.), On Law, Politics and Judicialization, Oxford University Press, Oxford, 2002. 
through some examples how the judicial power was and is still part of a governmental device that has contributed in production of social order through its function of partage, which today is quantitatively and qualitatively changed.

On different occasions Foucault underlined the importance of law for the creation of our forms of experience. ${ }^{2}$ This interest was made concrete in a series of analyses in which we believe a constant methodological core can be found, according to which the space of the trial is one of the places in which the strategic game which might prelude to a possible re-articulation of a regime of truth is decided and that can be inscribed, in short, in the "games of truth and error through which being is historically constituted as experience". ${ }^{3}$ From the Foucauldian point of view, judgment is 'populated' by different forces whose genesis needs to be investigated, which make judgment a pièce in the dramaturgy of the real. That means, in short, that judgment and trial are a sort of litmus test for understanding the changes of the juridical and moral experience and them political consistency. ${ }^{4}$

Judicial practices are made up of what Foucault called moral technologies, a concept involving the political technology of the body, the technologies of truth, the political technology of individuals, the technologies of the self, etc. In a certain circumstance Foucault defined the concept of governmentality like the interdependence between these technologies ${ }^{5}$, and in another one he explained that each correlation system between these technologies is qualified by the dominant technology ${ }^{6}$, with its rules, knowledge and forms of subjectivity. ${ }^{7}$ Indeed, the character of these technologies is in their being matrixes of practical reason. Their value is not ontological, but genealogical and strategic: they are the object of movements and re-uses which give them an importance which from time to time differs within the system in which they are used. The conditions which make one practice or another socially acceptable and legitimate in a given historical period are, for Foucault, an autonomous field of research because of their regularity, of their "reason" - a word which, for Foucault, does not refer to the extra

2. See, for example, M. Foucault, "La vérité et les formes juridiques", in Id., Dits et écrits I, 1954-1975, Gallimard, Paris, 2001, pp. 1406-1491; Id., Wrong-Doing, Truth-Telling. The Function of Avowal in Justice, University of Chicago Press, Chicago, 2014. 3. M. Foucault, The Use of Pleasure, Vintage Books, New York, 1990, pp. 6-7.

4. About judgment in Foucault, see F. Ewald, "Pour un positivisme critique: Michel Foucault et la philosophie du droit", in Droits, 3, 1986, pp. 137-42. On the above-mentioned points, see G. Brindisi, Potere e giudizio. Giurisdizione e veridizione nella genealogia di Michel Foucault, Editoriale Scientifica, Napoli, 2010.

5. L.H. Martin, H. Gutman, P.H. Hutton (eds.), Technologies of the Self: A Seminar with Michel Foucault, Tavistock, London, 1988, p. 13.

6. M. Foucault, Security, Territory, Population. Lectures at the Collège de France (1977-1978), Palgrave Macmillan, Houndmills, 2007, p. 8.

7. On this issue, see L. Bazzicalupo, "Governamentalità: pratiche e concetti”, in Materiali per una storia della cultura giuridica, 43, 2013, pp. 395-414. See also P. Fitzpatrick, B. Golder, Foucault's Law, Routledge, New York, 2009. 
temporal foundation of a phenomenon but to the strategy, which should be understood as the justification for phenomenal changes.

The strategic dimension of technologies emerges in the anti-Hobbesian conception of the civil war belonging to Foucault, for which it always works within the established power. An example is the constitution, in the 19th century, of a "dangerous class" which led to a transformation of legal rationality, because the criminological transcription of the crime and the re-codification of moral notions in criminal categories offered to power to punish the possibility of its extension to anomalies which were not included in the field of punishment. This was one of the uses of imprisonment, a practice which has allowed new procedures for objectification of the subject which, in relation to the higher 'describability' of subjectivity, have not only determined a lowering of the threshold of acceptability of punishing and being punished, but also a new awareness of judging in relation to the division between normal and abnormal subjects, normal and dangerous classes. ${ }^{8}$

A further constant element of Foucault's method, which is useful to investigate the creation of fields of experience, is the distinction between codes and moral technologies, in particular developed by his genealogy of ethics, but which may be traced back to the analytical scheme formulated in Discipline \& Punish in relation to the connection between codes, technologies and objects of judgment. The importance of this distinction may be understood if we analyse the genealogical perspective through which Foucault showed that both the differences between paganism and Christianity, and those which are inside Christianity itself, may be understood only if we free ourselves from a conception of moral history as a history of codes or behaviours, and recognize in it the history of the relations existing between codes and the ways through which the subjects establish a relationship with themselves. Foucault distinguishes two Christian regimes of truth: a regime that corresponds to the moral code, which is organized around showing one's own faith and has its basis in the act of submission and obedience, and another one that corresponds to moral technology and that is organized around the act and the obligation of truth, in the imperative given to the subject to decipher itself in confession as a subject of desire. ${ }^{9}$ It is in this relation between code and moral technology that Foucault recognizes an infinite series of compromises and frictions, which constitute the most proper characterization of Western moral history, marked by the perennial

8. On all these subjects see M. Foucault, La société punitive. Cours au Collège de France (1972-1973), Gallimard-Seuil, Paris, 2012, pp. 23-39.

9. M. Foucault, On the Government of the Living. Lectures at the Collège de France (1979-1980), Palgrave Macmillan, Houndmills, 2014. 
difficulty in conciliating juridical subject and subject of truth, hermeneutics of the text and hermeneutics of the subject, faith as adherence to a dogmatic content and faith as performative dire-vrai on one's self, ${ }^{10}$ and, in modernity, juridical subject and homo criminalis.

Such subjects will find their final definition in The Use of pleasure, where it is further specified that prescriptive values and rules are one thing, the real behaviours of individuals are another, and the way in which an individual should make himself or herself "an ethical subject acting in reference to the prescriptive elements that make up the code"11 is another thing again. Codes, values do not say anything about the ways in which they should be performed, elaborated or created, and the moral subject constitutes itself starting from behaviours on the basis of which he or she obligates himself or herself in relation to them. The integration of codes and prohibitions within a relationship with oneself is in fact always different, because, even when the code is the same, the elements constituting the how of moral experience, that is to say the ethical substances, the ways of subjection, the techniques and finally the teloi are always articulated in a different way.

Even though they are different in some aspects, we believe that genealogy of ethics and genealogy of prison have common methodological elements. In fact, with a more careful look, in Discipline \& Punish, beside the subject of law, Foucault identifies a series of punishable objects or subjective matters which constitute in judgment a double psychological-moral operating below the code, and it will not be difficult to recognise in this a methodological principle which is very similar to that used in The Use of pleasure. In relation to the changes in the criminal system at the end of the 18th century, Foucault underlined that, beyond the small changes made to some elements of the code, the most important transformation had to do with the object of criminal judgment through the creation of a new objectivity. ${ }^{12}$ What changed it was not the formal definition of the punishable element, but its quality, its substance: under the name of crime not only an object defined by the code, but also a series of anomalies, perversions and objects which cannot be qualified juridically but recognisable from a scientific point of view, were judged. In short, during modernity the object of judgment is not an act or a behaviour, but the way the subject is: judgment needs to know if the crime has already been written in the history of the subject, in his/her desire. As it is necessary to justify

10. M. Foucault, Wrong-Doing, Truth-Telling. The Function of Avowal in Justice, conferences III, IV and V. 
the decision by using psychiatric discursiveness, the judgment sees its own rationality threshold changed, as it inserts evaluations in its own device which do not belong to the juridical field, but to the describable individuality (and therefore punishable and correctable) of the disciplinary system. Here we have to record the creation of the modern soul, as well as a change in the forms of judicial experience, which may be brought to light by the analysis of the way in which codes are made to work through procedures of objectification of the subject.

To continue with our line of reasoning on the method, the genealogy of ethics presupposes that the identity of moral code does not imply the identity of the ways in which it is possible to be constituted as moral agents, while the genealogy of law presupposes that the identity of the criminal code does not imply the identity of the ways in which a subject can fall within a criminal action, and being judged and punished. Law has a dynamic element which is made by the way in which the punishable matters come into play. Besides the subjective matter into which a subject is divided starting from the discourses and practices which allow him or her to modify the relationship with himself or herself (confession of the crime or confession of who he is), there is therefore to consider the mode of subjection, that is to say all the reasons pushing a subject to recognise his or her moral or juridical obligations. The techniques through which we can modify ourselves in order to become ethical subjects have their equivalent in the techniques which allow the objectification of the subject and make it the object of possible knowledge and behaviour. Finally, there is the fourth element, the telos, the goal towards which we aim in a moral behaviour, which finds its correspondence in the aim implied in the punishment of a subject.

\section{The re-definitions of "judiciable" between government by judges and judicial governance: from the norm to the optimum}

What has been said so far allows us to recognize one of the specificities of Foucault's thought in the analyses of what may be defined as the continuous production and re-definition of the "judiciable" as a dimension peculiar to law. ${ }^{13}$ Such an analysis gives us the possibility of grasping the ways through which judgments are organised and justified, evaluating the confluence of heterogeneous elements in the judging 'unit' and

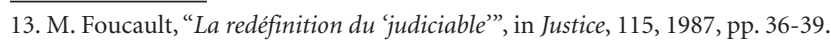


dividing this latter in order to make emerge the conflicts which shake it, the positions of value that support it. This will demonstrate what the horizon of rationality of judgments is, their origin, the reason for which we believe they are in some way justified. In short, it is about analysing the historical re-definitions of objects of judgment and of subjects of knowledge and therefore the becoming of the forms of judgment in the more general field of the economy of the relations of power. It is in this way that the power of the judges performs a function of social regulation, and not simply of creation of new law. It is enough to think that, according to Foucault, the expansion of the normative power of judges did not have to wait for the crisis of legislation as a regulatory force; in the criminal process, where it is more difficult to deviate from the principle of legality, judging is not in fact equivalent to applying legislation. It has been seen since the 19th century that law has been open to recognising concepts which were created outside itself, such as that of socially dangerousness, which has neither judicial nor medical nature and has a function that is substantialistic and individualizing in judgment.

As well known, the phenomena of internationalization and jurisdictionalization of law ${ }^{14}$ determined a new problematization of judgment in relation to multiple phenomena, among which the increased role of judges within contemporary democracies and apart from this (lex mercatoria), the role of International and Supranational Courts, and finally the dialogue between the Courts of different countries even though there is not any obligation in this regard. In this respect we talk about judicial governance, not to be confused with the government by judges, because its main characters are the inclusion of the private individuals in the decision processes and the action in the absence of the legislation. ${ }^{15}$

We believe that it is possible in the light of Foucault's analysis to make an attempt not only to explain the particular origin of the phenomenon, but to broaden the series of problems it gives rise to. These are problems about which Foucault started to think during the second half of the 70s, by analysing the dissemination of the judicial functions throughout the whole social body because of his increasing interest for the process of governmentalization of contemporary states.

In La redéfinition $d u$ "judiciable" Foucault says that the emergence of pluralism has forced the state to change regarding to its rationality, founded on the relation liberty/law. The basis of the new economy of power relations becomes the judiciary. Besides recalling the new functions assigned to judiciary, Foucault underlines the 
presence of judges in new bodies which are not exactly judicial whose functions of control within fields previously subtracted from the judicial sphere are multiplied. It is enough to think about the Authorities, institutions between the executive and the judicial branch having the task of controlling information, privacy, consumption, the relations between individuals and administration, etc. The creation of new fields of intervention for the judiciary determines a transformation of its rationality because, besides defining a division between lawful and unlawful beginning with legislation, it will also make further divisions, such as that between truth and falsehood, between what is physiologically good and physiologically harmful etc., without a code of reference. In short, the judicial institution has increasingly a regulatory function. And the protection functions have gradually turned not towards the individuals or the species, but towards the vulnerable behaviours and in view of the optimum of the social functioning, i.e. towards the protection of population from the pathological distortions of the complex system in which we live. The element characterizing the judicial decision becomes the establishment of this optimum, that is stated starting from the legislative activity which other knowledge exerts within it — what invalidates the Kelsenian paradigm of the qualification of facts and marks the belonging of judicial judgment more to the sphere of 'is' than the sphere of 'ought', in an inversion of relations between prescription and reality. ${ }^{16}$ It is therefore true that liberal governability, which limits itself in relation to the naturalness of phenomena (population, market) which it asserts to know, ${ }^{17}$ has progressively purported that it was the judicial field which sets the limits to the power and guarantees an effective government. The judge stands, in fact, as the holder of a certain number of truths on the optimum of freedom and security for the defense of the population against dangers, as the guardian of rights against the power, and as a public service to arbitrate the conflicts of a market society. For this Foucault has included the functioning of judges in that psychological and cultural correlate of liberalism which is the danger. ${ }^{18}$

This transformation of the 'judiciable' constitutes a new agreement between the state and citizens: no longer is it the warranty for peace within national frontiers, but protection from everything which might be a factor of uncertainty and risk. This has been revealed in Foucault's time, and it is also shown nowadays, threatened by both the

16. See S. Chignola, "In the shadow of the State. Governance, governamentalità, governo", in G. Fiaschi (ed.), Governance: oltre lo Stato?, Rubbettino, Soveria Mannelli, 2008, pp. 117-141.

17. M. Foucault, The Birth of Biopolitics. Lectures at the Collège de France (1978-1979), Palgrave Macmillan, Houndmills, 2008, pp. 24-25.

18. Ibid., pp. 70-71. 
terrorist menace and by the fact that protection is a permanent exception regarding laws. ${ }^{19}$

But in reality it is all the mechanics of the order that has been affirmed in the West to have led, according to Foucault, to a transformation of the fields of intervention of power and of the forms of experience, in virtue of which the extra-legal intervention of power is not perceived as an abuse, but as a "thoughtful attention." As the law cannot interfere on every occasion in which the woof of daily life is torn apart by a single exceptional event, security requires a saving power and authorizes a permanent state of exception. Such a state is required by forms of subjectivation that live life as a factor of danger, and in neoliberalism also as human capital to put in value, as they have internalized the enterprise form and evaluate (and evaluate themselves) through performance parameter.

In other words, the 19th and the 20th centuries have seen the affirmation in the West of an economy of power relations which is not based on the creation of a juridical architecture, but on a mechanics of the order ${ }^{20}$ where also judicial power is introduced. We can assume that if today at an international level we talk about global order it is because within state systems judges are no longer required to apply laws but to produce social order.

Through the consolidation of a disciplinary justice, of a justice for social defence having the task of determining, before code violation, an undetermined real danger, there is the progressive affirmation of a judge who is the creator of law also having a promotional attitude, but most of all there is the transformation of our forms of experience, of our self-perception of damage and responsibility, which nowadays can be potentially extended to everything — also because of the transformations of the constitutional state, of which Carl Schmitt and Ernst Forsthoff have underlined criticalities in relation to the bellicose logic of values.

If what we have said is plausible, then we can argue that the loss in the regulatory capability of the legislation, the request for security and norms and the fact of acting as a substitute for the political are an effect, not a cause, of the increase of the judicial 'offer', that is to say of the 'decision' of the West to govern pluralism through re-functionalising of the judicial power. Since modernity, the judicial power has found itself to benefit from a certain condition of acceptability and belief, and has found room in a logic which has allowed an imitative spreading of it, as Gabriel Tarde would have said,

19. M. Foucault, La sécurité et l'État, in Id., Dits et écrits, Gallimard, Paris, 1994, III, pp. 383-388. 20. M. Foucault, Technologies of the Self: A Seminar with Michel Foucault, p. 166. 
up to such a global level which in turn has determined the transformation of the logic itself, as we will try to show.

As it is clear, Foucault does not argue on the classical terms of the debate concerning the government by judges (founded on their capacity of creating law or on their lack of democratic legitimacy), and obviously he could not predict the global transformations of judiciary power, i.e. what is currently called judicial governance. Undoubtedly, this is different than the government by judges, not only quantitatively (because of the growth of the power and of the cases in which the judges intervene), but also qualitatively, because it includes new subjects in the decision process and acts in absence of law.

This does not prevent us, however, to use profitably Foucauldian categories to reinterpret the government by judges, and to interpret the judicial governance recognizing in it forms of continuity in the perspective of governmentality. ${ }^{21}$ If in fact we attribute to the idea of government a wider semantic spectrum, with Foucault we can rewrite the concept of government by judges extending it to the ordinary jurisdiction and to the quasi-judicial powers, as these have contributed in production of social order in a complex relationship with other powers, knowledge and forms of normativity that have been strategically related. Government by judges and judicial governance can then be framed in the common horizon of the judicial governmentality, that is the way through which judicial power integrates power technologies and produces social order beyond its fundamentals, i.e. legal and constitutional architectures. It is in this sense that one can say that the judges and the quasi-judicial powers govern, since they have a constituent power and they are able to lead the conducts, omnes et singulatim.

\section{Cases of Judicial Governmentality}

\section{The Global Prominence of Judicial Power}

We believe that the above-mentioned problems have taken on such an importance as to change the horizons of international rationality. And we can affirm that in a certain way the logic of the relation between judicial governmentality and global order

21. On the relationship between governmentality and governance, see S. Vaccaro, "Governança e governamentalidade", in N. Avelino, S. Vaccaro (eds.), Governamentalidade segurança, Intermeios, San Paolo, 2014, pp. 43-58. See also G. Borrelli (ed.), Governance, Dante \& Descartes, Napoli, 2004. 
repeats in a different form the relation between judicial power and democracy, as well as between judges and law, within national systems. The importance of non-state entities in international relations, and therefore the crisis of international relations formalized around states, repeat the emergence of forces and contradictions which have determined the transformation of rationality of the modern state. In fact, as the judicial power falls within the forms of government of pluralism within state systems, it also falls within global governance. Moreover, the deterioration of international legality and the absence of the predictability of decisions due to the supremacy of international tribunals in the formulation of criminal norm (as it happens in the ad hoc Courts) repeat the deterioration of the principle of legality in state systems. There is, then, another reason, which is very elementary: not only we had already a transnational expansion in the processes of judicial governmentalization of the national systems (because of the phenomena that they intended to govern), but the same governmentality that is based on the risk purports to overcome frontiers.

Remaining on an international level, international judges have also created a new category of crimes (crimes against peace, war crimes and crimes against humanity created by the Court of Nuremberg), and nowadays they play the role of law-makers in the formulation of criminal norm, ${ }^{22}$ and in this way they create and define forever international law, with the risk of a normative confusion also with reference to the definition, which is absent, of the function of punishment. ${ }^{23}$ Making up to Foucault's critique to Hobbes, particularly in the international field the transformations of the judiciary are a continuation of war with other means. As it is known, the punishment of war criminals in the Nuremberg and Tokyo trials was a continuation of the war in a juridical form, and such a politicalness is also present in the ITCY. Danilo Zolo has shown that the judicial profile of international courts has always been overshadowed or by the overlapping of military logic or by an ideological identification of their judging and examining members with the values and the expectations of Western countries, and has recognized in it a political justice in which the criminal process performs extra-judicial functions such as the stigmatization of the enemy or the expiatory sacrifice. ${ }^{24}$ For these reasons we believe we can subvert, again with Foucault, within the international context, the Clausewitz formula, and state that international

22. A. Esposito, "La définition des crimes et le rôle du droit comparé: comment les juges comblent les lacunes normatives", in E. Fronza, S. Manacorda (eds.), La justice pénale dans les décision des tribunaux ad hoc, Dalloz-Giuffrè, Milano, 2003.

23. R. Henham, "The Philosophical Foundations of International Sentencing”, in Journal of International Criminal Justice, 1, 2003, pp. 64-85.

24. D. Zolo, Invoking Humanity. War, Law and Global Order, Continuum International, London-New York, 2002. 
courts are the continuation of global civil war with other means. The new role of judicial truth implies a tribunalization not only of politics but of history itself.

On the other hand, judicial power is also one of the foremost players of supranational and transnational law. Considering the first aspect, the institutional architecture of the European Union was mostly created in a "judicial way" of creation of rules, as is attested by the leading role of the European Court of Justice. But see also the European Court of Human Rights - where the states can be sued by their own citizens — and its consequent repairing role, also starting from its dialogue with foreign courts. As far as the transnational law is concerned - leaving apart the transnational judicial dialogue which is going to be examined soon - just remember that on this level judicial power is a regulatory actor of commercial relations. Especially in this context a global market of law has been constituted, where there is a huge presence of private subjects that threatens to turn justice into a private good, serving an efficientist logic. In addition, due to the phenomenon of the forum shopping, the consumer of the law becomes the $\operatorname{arbiter}^{25}$ — what constitutes a sort of self-regulation.

And finally, through the Foucauldian point of view, judicial power is one of the foremost players of security governance. In fact, the European judicial network is being created only after the police network, and even at a global level a world cooperation network is being created in view of security against terrorism, without the existence in both cases of an European or a global criminal law. Even while recognizing in terrorism itself the problem of the security state, Foucault was worried about the fact that we were entering a regime in which fear and security increase one another. And also today, just like in the 19th century, after 9/11 the criminal is equalized to the enemy who fights against society, and fear is produced in relation to terrorism so that populations accept the agreement for security. Such an agreement has return effects in governing individuals, which use rights as an instrument for demands but accept without too many scruples the creation of a buffer (dangerous classes, rogue states, clandestine immigrants). As a matter of fact, in the domestic context the fight against terrorism is transformed into a selective criminal justice, into a war against immigration: the greater biopolitical interest in the life of vulnerable population is reflected in a thanato-political interest in the exclusion of danger, a sign of which is the current international criminalization of clandestine immigration. ${ }^{26}$

25. A. Garapon, La Raison du moindre État. Le néolibéralisme et la justice, Odile Jacob, Paris, 2010, pp. 189-196. Also, see D. Bifulco, "Il potere giudiziario", in F. Angelini, M. Benvenuti (eds.), Il diritto costituzionale alla prova della crisi economica, Jovene, Napoli, 2012, pp. 359-374.

26. In 2009, for example, an Italian Parliamentary Bill on security wanted to oblige doctors to report clandestine immigrants who asked for medical services to the judicial authority. Nowadays in Italy there is an administrativization of 


\section{Transnational Judicial Dialogue and Knowledge}

As it was said before, in the passage from modernity to contemporaneity the operativeness of the concept of law was neglected in favour of an endless modulation of law or of an acting in absence of it. This is what happens in that dialogue which is developed without a normative context and through more or less informal practices, that is to say in the dialogue between Courts of different countries, which might justify their decisions beyond the word of the legislator, by using arguments or by citing foreign sentences. Recalling foreign sentences or supranational courts strengthens in fact the independence of national judges, which is sometimes condemned for its potential abuse in relation to sovereign political choices or praised for the extension of the protection of human rights.

Now, even though the logic of human rights is pervading, rights as well as values are not worth for themselves, but as they are continuously re-evaluated. As a consequence it is necessary to be able to look at the practices of power and the technologies which constitute the substratum of values re-evaluation. For this reason, we will try to enunciate the problems put by such a practice in relation to the role of values and the knowledges which intervene in the global judiciary context.

In fact, the transmigration of values at an international level through judges ${ }^{27}$ is often under discussion but, as it was said, a value is one thing and another is the way to make it real. A same principle, a same value, and even a same juridical norm do not say anything on their own realization and may be historically defined in different ways, because there are forces which give them an interpretation and forms of subjectivization which structure themselves through these interpretations. It is therefore necessary to see how values are re-evaluated, in relation not only to interpretative techniques of judges but also to the way in which knowledges come into play in the definition of the objects of judgment.

Maybe the dialogue between the Courts might be as long as there is a horizon of governmental rationality which regards the knowledges which contribute to the definition of judgment. If for instance, in a case of end of a life, the Italian Court of Cassation ${ }^{28}$, without decrees by the legislator, could recall the ECHR, the New Jersey Supreme Court,

\footnotetext{
judiciary in relation to migrants, with a legal presumption of dangerousness (reversal of its original function of individualization) in case of judicial denunciation.

27. See B. Markesinis, J. Fedtke (eds.), Judicial Recourse to Foreign Law: A New Source of Inspiration?, UCL Press, London, 2006. 28. Cort. Cass. Sez I, sent. n. 21748, 16 october 2007.
} 
the Bundesverfassungsgericht, or the House of Lords, it was because there is an horizon of medical knowledge to which the judicial decision is subject, that of reaching an irreversible situation recorded according to the current technological possibilities.

The current neoliberal governmentality is on the other hand characterised by a constant concern for managing life and human capital, which has modified the same knowledge of the psyche. As it has been anticipated, it is referred to the logic of the optimum, to the growth of the operating capacities of the subject through the interference on its behaviors. ${ }^{29}$ The number of psychopathological entities has multiplied, getting to include the field ranging from invalidating psychotic forms to the conditions of temporary indisposition. Every behaviour associated with anxious states has become potentially risky, and each antisocial, compulsive or aggressive behaviour has become prodromic for possible psychopathological evolutions and liable of therapeutical intervention. ${ }^{30}$ The partition between normal and pathological became therefore less clear (continuous update of the DSM), and the change in the direction of a greater fluidity of medical forensic discursivenesses is probably one of the reasons why Italian Supreme Court $^{31}$, for example, has recently complied with that of other European countries, recognizing personality disorders as causes to prevent the imputability of the subject. Disorders of personality, meant as the incapability by the subject to manage his or her own capital, became subjective matters which can be judged within the criminal field, with the possibility for psychiatry to intervene also at the level of the smallest distortions of the behaviour, and with the possibility for the judiciary to extend punishment to elements which are not included in any criminal code.

\section{Governmentality and Security}

On the criminal policies aspect, it is a progressive development of importance of the power technologies and of the predictive knowledge, from the statistic point of view (actuarial practices) ${ }^{32}$ and today from the genetic one (homo neuronalis), in order to achieve the so-called selective incapacitation and to prevent the social dangerousness. This is the dominant function that qualifies the current governmentality. The bio-informatics has

\footnotetext{
29. See D. Tarizzo, "Dalla biopolitica all'etopolitica. Foucault e noi”, in Nóema, 4,1, 2013, pp. 47-50. 30. M. Bertani, "Postfazione”, in M. Foucault, Discipline, poteri, verità, Marietti, Genova-Milano, 2008, p. 258.

31. See Cort. Cass., Sezioni Unite Penali, sent. n. 9163, 8 march 2005; Cort. Cass., Sez. I, sent. n 16574, 3 may 2005, which recalls decisions and legislation of various European countries.

32. See B.E. Harcourt, Against Prediction: Profiling, Policing in an Actuarial Age, Chicago University Press, Chicago, 2007.
} 
already created a new horizon of reality that can transform the way of understanding of themselves and others, a new horizon of experience of biological knowledge. ${ }^{33}$

In this horizon the subject speaks without speaking and is known who he is without the verbalization of who he is. ${ }^{34}$ Nevertheless it is true that this type of discoursivity has not arrived yet to dominate judicial opinions, as Nikolas Rose maintains, although this biological conception of the person is becoming common-sense, and it will have a great value in determining the punishment, starting from the principle of the protection of society, as Rose himself argues. ${ }^{35}$ So if you think about the current passage from the homo psichologicus to the homo neuronalis which is shaping the new techniques developed by predictive medicine, that can attribute the deviancy to a genetic or neuropsychological deficit, and if you think about their extension to the criminal field, it will not be difficult to imagine a dangerous society of control which will totally re-define our games on the truth and the false.

Through this new technological horizon, justice is inserted in an economy of power based on control, considering also the importance assumed by electronic surveillance, which has the task to identify and track the individuals, or the big data profiling activity, which proceeds in direction of a preventive surveillance.

Theoretically, it cannot be excluded that these technologies can determine a new evidence of punishment and a function exclusively regulating the justice, ${ }^{36}$ except that imprisonment is increasing all over the Western world.

It can be observed, however, that, as the disciplinary technologies were designed to transform life into labor force and they posed an equivalence between form-prison and form-salary, today's technologies of the controlled society have the task of optimizing work performance through the control and they establish a regime of truth and power in which to the financial flow corresponds the traceability of the individual, just like the goods. It is not about only to withdraw the time from the subject and to discipline him, but to make him circulate in the most efficient way, marking out his route. Though there is a qualitative transformation of the regime of power and truth which has determined new forms of subjectivity, it remains the function of management and differentiation of the 'illegalisms' belonging to all the aforementioned technologies.

33. See F. Ewald, Assurance, prevention, prediction... dans l'univers du Big Data, Rapport pour l'Institute Montparnasse, Paris, 2012, p. 67.

34. In a different sense, even the utopia of the inquiry has stopped to rely on the word of the subject, turning to a confession of things. See G. Wajcman, Les expert. La police des morts, Puf, Paris, 2012.

35. N. Rose, The Politics of Life Itself. Biomedicine, Power, and Subjectivity in the Twenty-First Century, Princeton University Press, Princeton, 2007, pp. 234-235. See also K. Veitch, The Jurisdiction of Medical Law, Ashgate, Aldershot, 2013.

36. See V. Gautron, J.-N. Retière, Le traitement pénal aujourd'hui: juger ou gérer?, in Droit et Société, 88, 2014, pp. 579-590. 


\section{Cultural Governance}

Another aspect of judicial governmentality which is worth mentioning due to its effects of power and knowledge is related to the governance of cultural differences and to the judicial multiculturalism. Despite the judicial practices which recognize the value of the cultural defense have an overall rationality, the judicial space shows that the unity of legal orders has weakened, and that the judges have become actors of the cultural mediation. If it is possible to recognize in the process a form of heterotopia (i.e. a space where a plurality of different spaces, times, knowledge and powers are represented), and if one adopts an irenic image of judicial multiculturalism, it would be affirmed that into the judicial space the plurality of the world can find expression and composition. Nevertheless, not the best expressions in each culture are being compared in the judicial heterotopy, but the more problematic: singular practices, suffering voices, lives dragged under the gaze of the judge, in a game of power.

Now that the cultural sphere has become a judgeable subjective matter, the judges may get to establish what is culture and what is not. But behind every description of a culture hides a judgment on that same culture, a judgment that defines, as Pierre Bourdieu could say, the legitimate form of that culture, consequently producing numerous exclusions. The recognition of the legitimacy of a cultural practice contributes to determine the perception of self and others (especially in relation to the position of the non-citizens that count for nothing in the legitimate political field), and it constitutes the misrecognition, the negation - in the Freudian sense — of its arbitrary. In this context, the judge is a political actor of primary importance as he can achieve progressive or regressive, identitary or differential policies, according to the optimum of the social functioning.

Furthermore, as several scholars have shown, the reason that leads many judges to recognize the validity of the cultural argument in culturally motivated crimes is not the perception of diversity as a public good, but the belief that the subject has acted under the pressure of uncontrollable cultural inputs that have reduced its consciousness. ${ }^{37}$ And for this reason, it is claimed that it is necessary to integrate the psychological and anthropological knowledge. So, it is not a coincidence that the anthropological expertise asks the subject to tell the truth about himself, to give an account of his biography.

The activity of partage of the judge risks therefore to favor management practices of the population, because his decision may be part of a political practice of integration

37. I. Ruggiu, Il giudice antropologo, Franco Angeli, Milano, 2012, p. 201. 
that manages movements of good and bad diversity. ${ }^{38}$ And the legitimation of cultural profiling induces the danger of the inferiorization of a culture and gives legal value to an imaginary construction of the other as guilty in his own way of being.

\section{Conclusions}

On the light of the above, judicial governmentality is part of a global governmentalization process and it performs its primary task of government of flows through a selective activity directed towards the definition of the social optimum, in relation to the criminality, to the market, to the rights, to the relationship between cultures etc. The judiciary works in an heterogeneous logic which does not turn into homogeneity, ${ }^{39}$ according to the lines of privatization (forum shopping, arbitration), administration (authorities), constitutionalization (national, supranational and international courts) and expertization of judgment.

And especially this last line in the Foucault's point of view assumes a great importance. The judicial judgment interacts indeed strategically with operating knowledge which has no longer the function to tell the rule, but to say the optimum and to optimize the performances (of the state, of the individual, etc.). In both cases, the scientific knowledge doubles the object of justice and gives it a new form of reality. This fact modifies the comprehension of ourselves and others: if in disciplinary society the subject evaluates and evaluated itself through the grid of intelligibility of the norm, today it does so through the grid of intelligibility of the optimum. In this way, it goes from a judgment of normality and a form of interiority based on the norm to an optimization judgment and a form of interiority based on the enterprise, which will lead to the stigmatization not of the abnormals, but of those who "will not, for whatever reason, adopt an active, informed, positive, and prudent relation to the future". ${ }^{40}$

This contamination with knowledge stands like the foundation of the truth of the judgment, and hides the politicalness of the decision, as well as of the truth. Although the knowledge makes apparent the datum of the world as natural, we know that the datum is always produced by a certain treatment, and that the perception is always

\footnotetext{
38. A. Lentin, G. Titley, The Crises of Multiculturalism. Racism in a Neoliberal Age, Zed, London, 2011. See also S. Mezzadra, B. Neilson, Border as Method, or, the Multiplication of Labor, Duke University Press, Durham, 2013.

39. A. Tucci, "(Dis)aggregazioni”, in A. Tucci (ed.), Disaggregazioni. Forme e spazi di governance, Mimesis, Milano-Udine, 2013, p. 11 .

40. N. Rose, The Politics of Life Itself, p. 25.
} 
prejudiced by the configuration of knowledge and power in which it is located. The problem is not therefore the dialogue among judges, the realization of values or the normativity of knowledge, but the belief that their articulation can be performed in only but one way, which is deemed as correct and true, which will no longer be one of the many possible ways of what is possible, but a need. There is, indeed, a strong risk that judicial governmentality depends on the determinations of economical, medical, psychological and neurological knowledges and practices, and in general from the efficientist downhill which is overcoming the public sphere. The fact that our judicial systems go towards an increasing individualization of judgments and punishments should ask for an effort of elaboration which is able to bring it about or at least to problematizing what has been consolidated in common sense, that is to say the expertising as the result of our moral history. The pervasive becoming of judicial functions creates the possibility to express evaluations which cannot be controlled and are the seed of a new possible judicial abuse to which it is possible to react only promoting a new judicial question like the one of the Enlightenment.

If Foucault could appeal the universal form of the law and wish a new Beccaria, this form of problematization does not appear so important in the global world, though not in relation to the criminal policies of the states. Precisely because judicial governance is part of a larger phenomenon of governamentalization of the law, then it is on this field that one has to react. In a society like ours, the law should protect not only what we are, but also the effort to be different from what we are. In this sense, the struggle for rights has to take place by imposing a right of the governed ${ }^{41}$ to the judicial governmentality, and, in any case, new ways to realize a global legality. ${ }^{42}$

41. See S. Chignola (ed.), Il diritto del comune. Crisi della sovranità, proprietà e nuovi poteri costituenti, Ombre Corte, Verona, 2012.

42. See G. Palombella, Ė possibile una legalità globale? Il Rule of Law e la governance globale, il Mulino, Bologna, 2012. 